\title{
Enhancing ICT Competency for Teachers in the Thailand Basic Education System
}

\author{
Chaiya Akarawang ${ }^{1}$, Pachoen Kidrakran ${ }^{1} \&$ Prasart Nuangchalerm ${ }^{1}$ \\ ${ }^{1}$ Faculty of Education, Mahasarakham University, Mahasarakham, Thailand \\ Correspondence: Chaiya Akarawang, Faculty of Education Mahasarakham University, Mahasarakham, Thailand. \\ Tel: 89-619-9208. E-mail: chaiya_aka@hotmail.com
}

Received: December 3, 2014 Accepted: March 6, 2015 Online Published: May 27, 2015

doi:10.5539/ies.v8n6p1

URL: http://dx.doi.org/10.5539/ies.v8n6p1

\begin{abstract}
Information and communications technologies (ICT) competency has been identified as a deficiency in teacher training in the basic education system of Thailand. This research aimed to study needs and training for enhancing ICT competency. Some 377 teachers from 35 schools and 12 school directors, supervisors and professional teachers were surveyed to identify training problems and needs. The results found that teachers require training focused on achieving better practical skills and understanding towards ICT. Current training does not adequately support creation and use of ICT media in instructing students. Guidelines to successful training were identified as including proper needs assessments of teachers before training, development of interesting and useful training curriculum in association with teachers, and use of blended training methods (traditional lecture-based training plus internet-based training).
\end{abstract}

Keywords: ICT competency, teacher training, basic education, needs, training

\section{Introduction}

The eleventh national economic and social development plan of Thailand (2012-2016) emphasizes integration of human, social, economic, environment and political concerns into the teaching curriculum based on a commitment to life-long learning (National Economic and Social Development Board, 2012). The plan supports a modern approach to supporting, creating and enhancing information and communications technologies (ICT) education amongst teachers and students (Ministry of Information and Communication Technology, 2009). There is consensus with this approach from the Ministry of Education including in the ministry's vision for 'Enabling Future Education with ICT' and associated strategies (Ministry of Education, 2011). These strategies emphasize continual education and development of teachers in ICT competencies (Office of the Education Council, 2011).

All government sectors advocate that ICT education should be driven by professional teachers. Teachers must gain suitable knowledge and abilities to use ICT to effectively teach students. The Teacher Council of Thailand (2005) developed minimum specifications of ICT competency and computer skills for teachers. The Office of the Basic Education Commission has further specified research to enhance ICT competency (Office of the Basic Education Commission, 2010a). Teachers obviously play a key role in developing ICT skills within students and must be effective in this role (Atagi, 2002). The Office of the Education Council (2011) has assessed education standards since 1999 and has consistently identified problems in education technology development and training.

To live, learn and work successfully in an increasingly complex, information-rich and knowledge based society, students and teachers must utilize technology effectively. Within a sound educational setting, technology can enable students to become capable information technology users, analyzers, problem solvers and decision makers. Without adequate ICT skills students will be increasingly squeezed out of the productive work force (The United Nations Educational, Scientific and Cultural Organization, 2008; Ruangsuwan, 2005).

ICT are making dramatic changes in economic and social development. These changes go beyond a mere increase in the number of computers appearing in work places, homes and schools. The role of ICT in schools is shifting dramatically. The traditional role of ICT in Thailand has been that of a minor curriculum subject sometimes called informatics, computer literacy or keyboarding. Alternatively, it has been used as an instructional aid to help students learn other subjects (Kozma, 2002). ICT play a critical role in enhancing the quality of education and are important in helping teachers and students perform more effectively. To make the 
best use of ICT, teachers must be equipped with adequate ICT competencies. In the process of integrating ICT into education both teachers' ICT competencies and how they perceive the role of ICT in their teaching/learning processes play key roles. Analysis, design, development, implementation, evaluation, and management of ICT in education require diversified competencies and knowledge (Goktas, 2009).

Teachers and students need to fulfill certain technology criteria in terms of classroom activities to promote self-directed learning (Office of the Education Council, 2009a, p. 8; Queensland University of Technology, 2002; Atagi, 2002). Teachers must develop ICT competency and ICT should be a priority in training curricula. Identification of training needs to enhance ICT competency for teachers in the Office of the Basic Education Commission is the basis for further ongoing research, including in this paper.

\section{Methodology}

This research commenced with a literature reviews to identify relevant theory, concepts and research related to ICT competency training (discussed throughout this paper). A survey technique was used to identify and address key ICT training needs and competencies. A total of 377 teachers from 35 schools in the northeastern part of Thailand were surveyed using a standardized questionnaire. A summary of the characteristics of the participants is at Table 1 . Most teachers surveyed were female (71.62 \%), 50 years or older $(37.14 \%)$ and had a Bachelor degree level $(76.66 \%)$.

The survey included questions directed at ICT competency and training needs using a rating scale of 1-6 (highest, very high, high, low, very low, and lowest). The survey was conducted through mail services in the first semester of the 2013 academic year. The results were analyzed by frequency, percentage and on a descriptive basis.

In addition, standardized interviews were conducted with 12 stakeholders to elicit further information and ideas. These stakeholders comprised 4 school directors (principals), 4 teacher supervisors and 4 professional teachers.

Table 1. Characteristics of participants

\begin{tabular}{llll}
\hline Characteristic & Categories & Number & Percentage \\
\hline Gender & Male & 107 & 28.38 \\
& Female & 270 & 71.62 \\
\hline Age & 20-29 years & 48 & 12.73 \\
& 30-39 years & 95 & 25.20 \\
& 40-49 years & 94 & 24.93 \\
& 50 years or older & 140 & 37.14 \\
\hline Education level & Lower than bachelor degree & 10 & 2.65 \\
& Bachelor & 289 & 76.66 \\
& Masters & 77 & 20.42 \\
& Doctorate & 1 & 0.27 \\
\hline
\end{tabular}

\section{Results}

The survey divided ICT competency into cognitive ability, skills and attitude. For the purposes of this research, cognitive ability and skills were defined as the ability to identify and use: computers, tablets and smart phones; the internet; networking with others; instructional media (including Microsoft Office); ICT knowledge; Thailand ICT law; and Thailand ICT morals. Attitude was defined as the extent of participation in ICT development training, ICT user awareness and ICT information use. 
Table 2. ICT competency of surveyed teachers

\begin{tabular}{|c|c|c|c|}
\hline Data & Categories & Number & Percentage \\
\hline \multirow[t]{5}{*}{ What IT device do you have? } & Nothing & 26 & 6.90 \\
\hline & Personal computer & 180 & 47.75 \\
\hline & Lab top computer & 299 & 79.31 \\
\hline & $\mathrm{iPad} /$ Tablet & 122 & 12.73 \\
\hline & iPhone/Smart Phone & 122 & 32.36 \\
\hline \multirow[t]{5}{*}{ Do you use internet? Where do you use the internet? } & Nothing & 32 & 8.49 \\
\hline & Using & 346 & 91.78 \\
\hline & At home & 213 & 56.50 \\
\hline & At work & 285 & 75.60 \\
\hline & Another; restaurant, coffee shop & 20 & 5.31 \\
\hline \multirow[t]{5}{*}{ Do your office have internet and how fast is it? } & Nothing & 0 & 0.00 \\
\hline & Have & 377 & 100.00 \\
\hline & Slow & 86 & 22.81 \\
\hline & Moderate & 259 & 68.70 \\
\hline & Quick & 32 & 8.49 \\
\hline \multirow[t]{5}{*}{ How many hours do you use internet per day? } & Nothing & 39 & 10.34 \\
\hline & $1-2$ hours & 179 & 47.48 \\
\hline & 3-4 hours & 99 & 26.26 \\
\hline & $5-6$ hours & 42 & 11.14 \\
\hline & More than 7 hours & 18 & 4.77 \\
\hline \multirow[t]{2}{*}{ Where do you prefer to do training? } & School & 214 & 56.76 \\
\hline & Outside school & 163 & 43.24 \\
\hline \multirow[t]{3}{*}{ What method do you prefer to do training? } & Classroom training & 98 & 25.99 \\
\hline & Web-based training & 12 & 3.18 \\
\hline & Blended training & 267 & 70.82 \\
\hline
\end{tabular}

Note. Table 2 shows relevant ICT competencies amongst the survey participants. In summary, $93.10 \%$ of teachers have an IT device(s) connected to the internet, $91.72 \%$ use computers and $91.51 \%$ use the internet. All teachers' offices (schools) have internet with $100 \%$ rated at a moderate speed. Teachers use the internet at school $75.60 \%$ (compared to home or other places) and $70.82 \%$ expressed a preference for blended training methods in ICT training courses.

Table 3. Opinions of teachers on current ICT training

\begin{tabular}{llcc}
\hline Item surveyed & \multicolumn{2}{c}{ Level of opinion } & \multirow{2}{*}{ Interpretation } \\
\cline { 2 - 3 } & $\bar{X}$ & S.D. & \\
\hline Training Institute (body conducting the training) & & & \\
$\begin{array}{l}\text { 1. Training Institute did not undertake a needs assessment to } \\
\text { identify my ICT training needs. }\end{array}$ & 4.25 & 1.09 & rather more \\
$\begin{array}{l}\text { 2. Training Institute did not specify competency standards to } \\
\text { be achieved. }\end{array}$ & 4.03 & 1.05 & rather more \\
$\begin{array}{l}\text { 3. Training Institute did not evaluate the ICT competency of } \\
\text { trainees before training. }\end{array}$ & 4.12 & 1.12 & rather more \\
\hline
\end{tabular}




\begin{tabular}{l}
$\begin{array}{l}\text { 4. I don't understand the object of training, what knowledge } \\
\text { or skills were sought. }\end{array}$ \\
\hline
\end{tabular}

\section{Training Curriculum}

5. Training curriculum wasn't problem solving.

$3.57 \quad 1.13 \quad$ rather more

6. Training curriculum didn't meet my need assessment.

3.57

1.16

rather more

7. Training method wasn't suitable and the object of the training was not met.

1.11 rather more

8. Training media wasn't suitable and the object of the training was not met.

1.13 rather more

9. Training activity wasn't of interest and made me bored.

3.55

1.13 rather more

10. I participate in training.

3.80

1.18

rather more

11. Trainees had difference competencies and different interest.

4.40

1.10 rather more

12. Training activity was descriptive and did not have sufficient practical exercises.

4.02

1.11 rather more

Training Opportunity

13. Training Institute had limited number trainee places.

rather more

14. My school did not participate in training.

rather less

\section{Training Time}

15. Training was of insufficient time.

1.14 rather more

16. Training was at the same time as my teaching duties.

4.42

1.22

rather more

17. I had too much work and could not do the full training.

3.64

1.38

rather more

Training Budgeting

18. My school has insufficient money for my training.

$4.12 \quad 1.37 \quad$ rather more

19. Training Institute does not have money for my training.

4.09

1.30

rather more

\section{Training Location}

20. Training location is distant and difficult to attend.

3.96

1.28

rather more

21. Training location is not suitable.

rather more

\section{Training Sources}

22. Training did not use appropriate ICT media.

rather more

23. I can't review training because no notes were provided.

3.72

1.26

rather more

Training Following and assessment

24. Training Institute did not show criterion for training.

rather more

25. Training Institute did not assess the effectiveness of the training.

rather more

26. Training Institute did not offer adequate post-training follow-up and support.

$\begin{array}{lll}4.14 & 1.25 & \text { rather more } \\ 3.84 & 1.19 & \text { rather more }\end{array}$

Average Total

3.84

1.19

rather more

Note. Table 3 summaries the opinions of teachers on current ICT training based on a 1-6 rating scale (highest, very high, high, low, very low, and lowest). The results indicate 3 key problems including training being conducted during teaching time (media score 4.42), teachers in training classes having different competencies and interests (median score 4.40) and training not being directed at the actual and practical needs of teachers (median score 4.25). 
Table 4. Requirements to enhance ICT competency

\begin{tabular}{lccc}
\hline Item survey & $\bar{X}$ & S.D. & Level of needs \\
\hline 1. Internet and networking & 4.63 & 1.21 & Very high \\
2. General computer uses & 4.52 & 1.20 & Very high \\
3. Instruction media & 4.67 & 1.27 & Very high \\
4. Microsoft Office using & - & - & - \\
4.1 MS Office Word & 4.27 & 1.40 & High \\
4.2 MS Office Excel & 4.35 & 1.37 & High \\
4.3 MS Office PowerPoint & 4.35 & 1.42 & High \\
4.4 MS Office Access & 4.38 & 1.39 & High \\
5. ICT knowledge & 4.28 & 1.28 & High \\
6. Law and moral in ICT uses & 4.03 & 1.30 & High \\
7. Tablet PC & 4.38 & 1.35 & High \\
\hline
\end{tabular}

Note. Table 4 summaries teachers' identified needs to enhance their ICT competency based on the same 1-6 rating scale. Key needs are instructions and training on creating suitable electronic media for teaching students (e.g. CAI, WBI, e-Learning, e-Book (median of 4.67)) use of the internet and networking (median of 4.63) and general computer skills (median of 4.52).

Other ICT issues raised by teachers included concerns that budgeting for training was not adequate and that the training curriculum tended to take a 'top down' lecturing approach and wasn't problem solving. Other comments were that training activities were descriptive rather than practical, trainees had different competencies (meaning that training classes were inefficient) and that attendance at distant training venues was difficult for small schools. Poor after-training assistance meant that difficulties in practical implementation could not be addressed.

The survey found that more than $40 \%$ (less the category of 50 years old teachers) of teacher used ICT in instructing students. In general, younger teachers appeared to have good ICT competency and instructional capacity (perhaps a reflection of their more recent qualifications). Another positive outcome was that most schools were seen as having adequate IT resources and internet connections.

The in-depth stakeholder interviews identified a number of issues, including that the training curriculum was created by the Center of Education and did not respond to the needs of trainees. Similar issues were identified as from the questionnaire results including lack of a needs assessment of the trainees and lack of a problem solving focus for the training curriculum. Stakeholders suggested that assessment analysis was needed to group trainees with similar competencies. Lack of personnel to assist post-training was also identified as a key issue. According to the stakeholders, budgetary issues also placed constraints on training and revision of the training curriculum.

All interviewees agreed that blended training was preferred over either traditional training methods or sole web-based training. Because internet coverage was wide, ICT education offered potential economies over long time scales, broad geographic scales and could promote interactive learning. Trainees could still ask questions or collaborate their learning with other trainees and instructors on web-based training if proper electronic media were used. Stakeholders suggested that training should cover the training process as well as principals and theory. Trainees groups should be the same level of competency to promote more effective learning.

\section{Discussion}

The Thailand standard of ICT competency recognizes 3 elements: cognitive ability, skills, and attitude. The researcher used a synthesised measure of ICT competency from this standard to develop the study method and survey questions. The study confirmed previous studies that found teacher ICT competency to be at a low to middle level (Sanglub, 2007).

Training problems identified in this survey included that the training curriculum was not based on a teacher need assessment, training locations were distant, training time was limited, training was based on an outdated curriculum, training notes were not recorded and could not be reviewed, and training lacked evaluation and post-training support. These results are similar to Nilsook (1999) and Morrison (2009).

Research undertaken as part of this study, and the in-depth interviews, suggested that successful ICT teacher 
training Thailand should include:

- Training needs assessment undertaken by both training institutes and individual teachers to better direct and inform the training curriculum (ideally this should incorporate feedback and discussions between trainers and representative teachers).

- Training activities to have a practical focus and cover specific learning steps (including evaluation and post training).

- Opportunities for trainees to participate both before and after training.

- Blended training (incorporating both traditional class room training and internet training) to take advantage of wide internet coverage amongst teachers and economies of scale.

Ways to enhance ICT competency suggested by the survey included to create innovative delivery media such as CAI, WBI, e-Learning and e-Books. These have also been suggested by the Teacher Council of Thailand (2005). The Office of the Basic Education Commission (2010b) has specified behaviors for teachers in ICT using media, innovation and instruction for suitable content and activity learning. This indicator was the one of the ICT functional competencies for teachers used in this study.

The stakeholder interview group, in supporting blended training, suggested that training websites should be of interesting design and have many practical ideas for teacher needs. The websites should promote collaboration between training participants and include photographs and linkages to social media. Such websites would need to be regularly and automatically updated. Reinforcement for successful completion of internet training should be provided through certificates, working awards, social media recognition and other support for trainees teams engaged in collaborative learning.

\section{Conclusion}

ICT competency is very important for teachers in the $21^{\text {st }}$ century and $2^{\text {nd }}$ decade of Thailand's education reform. Thailand's schools have good internet coverage, but this survey confirmed poor teacher ICT understanding and competency. In particular, teachers see training in creation of electronic media for use in teaching students as a priority.

The survey identified many problems in ICT training and highlighted that a move towards blended training methods may be more effective in enhancing training for ICT competency. Blended training is still a relatively new concept in Thailand and combines both traditional training and web-based training. The benefits of traditional training-classroom and group interaction-may be combined with the benefits of web-based training including greater numbers of participants and flexibilities in scheduling. Trainees are typically introduced during the traditional training which can be shorter and aimed at greater numbers of participants. Participants can then use these contacts during the more detailed follow-up web-based training including through social media, e-mails, shared research, chat rooms and download sites.

Some $70 \%$ of teachers expressed a preference for blended training. Identified benefits included that teachers could study the training content and undertake training in logical steps or modules at their leisure. This avoided some of the limitations on time, training availability and travel imposed by traditional training and as identified in the survey. Web-based training also allowed teachers to work on real examples and gain valuable practical experience that was lacking in current training methods.

Web-based training still presents problems for teachers due to poor understanding of ICT media and lack of interaction with other trainees. Teachers in Thailand, in particular, may benefit through group interactions and socializing available in traditional training. Learning as a group allows more ideas to be thrown in and may generate practical discussions and directions to implement the training to the benefit of all participants.

In conclusion, this study confirmed poor ICT competency amongst Thailand's teachers and identified reasons why current training is not effective. The study supports a change in current ICT training methods to incorporate blended training techniques to improve training effectiveness.

\section{Acknowledgments}

This research was supported by the 2014 annual graduate theses and dissertations grant program supported by the Graduate School of Mahasarakarm University in North East Thailand. Thanks to Professor Pachoen Kidrakran and Professor Prasart Nungchalerm who supported the research. Thanks also to Mr. Steve Mercer who assisted in manuscript preparation. 


\section{References}

Apichatsei-nee, T. (2007). A Study of competency in information and communication of teachers teaching Thai education group, cluster 1. Master of education degree program in technology and communication education. Surindra Rajabhat, University.

Atagi, R. (2002). The Thailand educational reform project school reform policy. ADB TA 3585-THA Education Sector Reform.

Chuenjit, P. (2007). A Study of competency in information and communication of teachers teaching social studies, religion and cluster, cluster 1 education group, Sisaket educational service area office 1. Master of education degree program in technology and communication education. Surindra Rajabhat, University.

Goktas, Y., Yildirim, Z., \& Yildirim, S. (2009). Investigation of K-12 Teachers' ICT Competencies and the Contributing Factors in Acquiring these Competencies. The New Educational Review, 17(1), 276-294.

Kozma, R. (2002). ICT and educational reform in developed and developing countries. Center for Technology in Learning, CA: SRI International.

Landers, R. (2009). Traditional Web-based and Hybrid Instruction: A comparison of Training Methods (Dissertation of Philosophy, The University of Minnesota, USA).

Ministry of Education. (2011). Master plan information and communication technology education in Thailand (2011-2013). Bangkok.

Ministry of Information and Communication Technology. (2009). Master plan information and communication technology Thailand (2009-2013). Bangkok.

Morrison, M. (2012). Six big problems with training and development. Retrieved from $\mathrm{http} / /$ rapidbi.com/six-big-problems-with-training-and-development

National Economic and Social Development Board Office of the Prime Minister Bangkok, Thailand. (2010). The eleventh national economic and social development plan (2012-2016). Bangkok, Office of the Prime Minister Kingdom of Thailand.

Nilsook, P. (1999) WBT: Web-based training is ICT for training teachers in the future. Kasetsart education review. Kasetsart University.

Office of the Basic Education Commission. (2010a). Guideline of research and research Education support. Bangkok, J.N.T. Publish.

Office of the Basic Education Commission. (2010b). Teachers competency evaluation (Edition version). Bangkok.

Office of the Education Council. (2009a). The suggestion of education reform in decade2 (2009-2018) (4th ed.). Pitwang Graphic Publishing, Bangkok.

Office of the Education Council. (2011). Strategy of produce and development human education reform in decade2 in Thailand (2009-2018). Bangkok, Office of the Education Council, Ministry of education.

Queensland University of Technology. (2002). Teacher Development for Quality Learning. 2 George Street, GPO Box 2434 Brisbane, Australia.

Ruangsuwan, C. (2005). A Paper of academic conference: Standard of teachers' ICT competency in 21th century. Thailand Technology festival on 1-2 December 2005.

Sanglub, T. (2007). A Study of competency information of technology mathematic teachers related mathematic education group, cluster 2 education group. Master of education degree program in technology and communication education. Surindra Rajabhat, University.

The Teacher Council of Thailand. (2005). Standard of Education Professional. Bangkok, The Teacher Council of Thailand.

The United Nations Educational, Scientific and Cultural Organization. (2008). ICT Competency standard for teachers. Printed in the United Kingdom.

Warampha, S. (2008). A Study of competency in information and communication of teachers teaching Thai language cluster 3 education group, Sisaket educational service area office 1. Master of education degree program in technology and communication education. Surindra Rajabhat, University. 


\section{Copyrights}

Copyright for this article is retained by the author(s), with first publication rights granted to the journal.

This is an open-access article distributed under the terms and conditions of the Creative Commons Attribution license (http://creativecommons.org/licenses/by/3.0/). 